\title{
The Use of Ionic Implantation for The Medical Materials Modifying
}

\author{
Vitalii Honcharov*1, Illya Skarha-Bandurov ${ }^{1}$, Valery Zazhigalov ${ }^{2}$ and Nataliya Vasilenko ${ }^{3}$ \\ ${ }^{1}$ Department of Medical and Biological Physics, SE Lugansk state medical university, Ukraine \\ ${ }^{2}$ Department of oxidative heterogeneous-catalytic processes, Institute for Sorption and Problems of Endoecology of National Academy of Sciences of Ukraine, \\ Ukraine
}

${ }^{3}$ Institute of chemical technology (Rubizhne) of Dahl East Ukrainian National University, Ukraine

Received: 制: November 19, 2018; Published: 鴊: November 29, 2018

*Corresponding author: Vitalii Honcharov, Department of Medical and Biological Physics, SE Lugansk state medical university, Ukraine

\begin{abstract}
The modern industry of medical materials production is experiencing significant development. On the one hand, this is due to the expanding of capabilities of treatment technologies that require new materials and their characteristics. In this case, problems like materials for medical instruments and for implants are actual. On the other hand, industrial technologies for the synthesis and processing of materials that can be used in medicine are developed. And although the choice is very large, stainless steels that contain chrome and titanium are still widely used. They have the necessary mechanical characteristics and biocompatibility. One of the ways to succeed in creating such a modern medical material is surface modifying already existing metals and alloys. A promising direction in the synthesis of new materials using the modifying surface is the method of ionic implantation, the essence of which is the introduction of high-energy target ions in the surface layer and their accumulation with the subsequent creation of a surface film. Thanks to this the new distribution of surface energy and change of mechanical, physical-chemical, optical, and other characteristics of the processed sample are achieved. Therefore, in the work we investigated properties of stainless steel and steel ShKh15 as the materials that are widely used in medicine after the ionic implantation. It is shown that as a result of the ionic implantation the hardness and strength of the surface for steel 12Cr18Ni10Ti and steel ShKh15 was increased. It was established that the roughness decreased for both materials. It was shown that the corrosion resistance of stainless steel sample increased. Thus, ionic implantation has significant prospects as a technology for creating medical materials.
\end{abstract}

Keywords: Medical Material; Surface Modifying; Ionic Implantation; Hardness; Sclerometric Analysis

\section{Introduction}

Modern medicine is not possible without the use of steel tools and implants. Usually, in order to meet the needs of physicians, manufacturers of tools use chrome and chromium-nickel corrosionproof alloy steels 30Cr13, Cr13 40, 95Cr18 [1,2], AISI 301 (similar to $07 \mathrm{Cr} 16 \mathrm{Ni}$ ), AISI 316L (analogue 03Cr17Ni14Mo3) [3,4] for multiple uses and special alloys [5] and steel ShKh15 (analogue 52100) [2] for disposable products. To produce materials that are in contact with biological media also often stainless steels [6] are used. But in this case steel is required much corrosion resistance and wear resistance [7]. While the key issue is the biocompatibility of the material of the implant and the environment in which it works [8]. One of the ways to succeed in creating such a modern medical material is surface modifying already existing metals and alloys [9]. A promising direction in the synthesis of new materials using the modifying surface is ion-plasma technologies, in particular, the method of ionic implantation [10-14]. The essence of ionic implantation, as technology of impact on the properties of materials, is the introduction of high-energy target ions in the surface layer and their accumulation with the subsequent creation of a surface film. Thanks to this the new distribution of surface energy and change of mechanical, physical-chemical, optical, and other characteristics of the processed sample are achieved. Therefore, the purpose of the work was to investigate the properties of stainless steel and steel ShKh15 as the materials that are widely used in medicine, after the ionic implantation.

\section{Synthesis of Samples and Methods of Investigation}

Treatment of the samples was carried out by titanium ions in nitrogen plasma using installation of ionic implantation (Figure 1). Mode of implantation corresponded to fluence near $5 \cdot 1017 \mathrm{c}^{\mathrm{m}-2}$. The energy of the ions was about $20 \mathrm{keV}$. It allows to introduce them to a depth of up to 1 micron. The pressure in the vacuum chamber, which 
provided the ion jet did not exceed 10-4 Pa. Research of the surface hardness were carried out using the device "NOVOTEST T UD". Sclerometric analysis of adhesive properties was performed with the help of a microhardness meter "PMT-3". The state of the surface was shown wits using optical microscopy (microscope "MIM7", additionally equipped with digital camera "Kodak Easy Share C1013"). Corrosion resistance was tested for long-term exposure to solutions of sulfuric acid and with subsequent gravimetric analysis.



Figure 1: General view of the installation of ionic implantation

\section{Results and Discussion}

As a result of the studies a substantial increase in the hardness and strength of the surface for steel 12Cr18Ni10Ti and steel ShKh15 was received. In particular, the hardness for steel 12Cr18Ni10Ti increased from $220 \mathrm{HB}$ to $280 \mathrm{HB}$. The hardness of treated steel ShKh15 sample was changed from $2 \mathrm{GPa}$ to $4 \mathrm{GPa}$. This data indicate about the strengthening of surface layer and increase the durability of the material in terms of friction. Mechanical strength of the surface layer increased too (Table 1). One of the reasons for strengthening the surface is changing of the material structure. The results of optical studies (Figures $2 \& 3$ ) indicate about changing in the roughness of the surface in the direction of smoothing. Since stainless steel is intended for reusable medical materials, it must maintain a long term contact with the biological environment. Therefore, studies on corrosion stamina were conducted. Endurance stainless steel sample (12Cr18Ni10Ti) for 500 hours showed that depth of the dissolved layer for untreated material is about $400 \mu \mathrm{m} /$ year. Instead, steel with titanium ions had a value of no more than $12 \mu \mathrm{m} /$ year.

Table 1: Mechanical strength of the surface layer.

\begin{tabular}{|c|c|c|}
\hline Sample & \multicolumn{2}{|c|}{ Strength of Adhesion-Cohesive bond, GPa } \\
\hline & of initial sample & of treated sample \\
\hline steel 12Cr18Ni10Ti & 1,7 & 5,3 \\
\hline steel ShKh15 & 0,6 & 1,6 \\
\hline
\end{tabular}

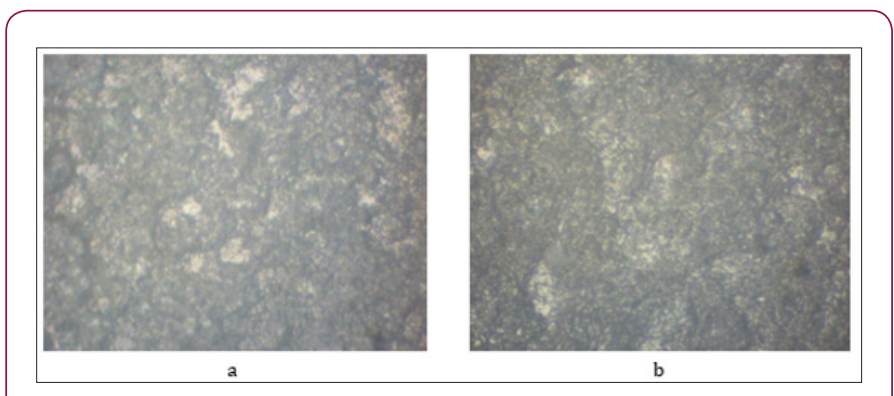

Figure 2: Microphotographs of steel ShKh15 structure:

a) Initial sample

b) Sample after implantation with an optical magnification $\times 500$.

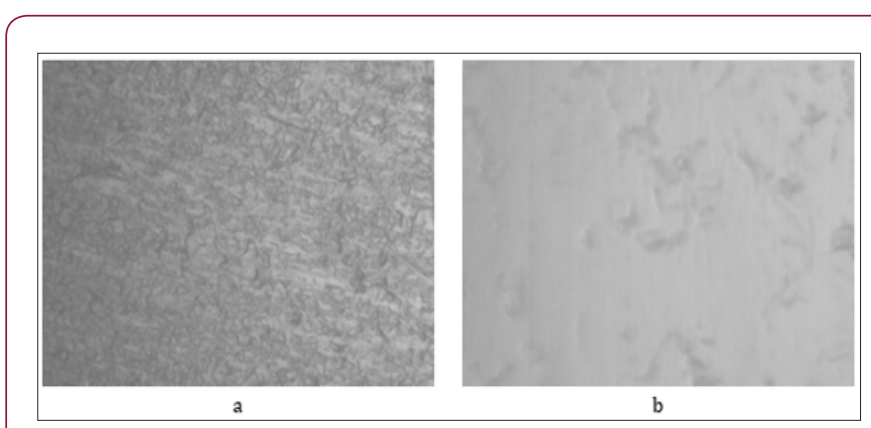

Figure 3: Microphotographs of steel 12Cr18Ni10Ti structure:

a) Initial sample

b) Sample after implantation with an optical magnification $\times 1500$.

\section{Conclusion}

Consequently, studies have shown significant prospects for the use of ionic implantation technology for the production of metal medical materials. The increased hardness and strength of the surface layer will ensure the use of treated steel as a material for tools. Mechanical properties in a heap with increased corrosion resistance indicate the potential for application of samples in the function of implants.

\section{References}

1. Korol MD (2008) Materialoznavstvo v stomatolohiyi. Vinnytsya: NOVA KNYHA pp. 240.

2. http://mirznanii.com/a/149996/instrumenty-meditsinskiemetallicheskie.

3. https://matmatch.com/blog/2018/04/06/metals-commonly-usedsurgical-instruments.

4. https://www.wpiinc.com/blog/post/which-alloy-is-best-for-mysurgical-instruments.

5. Kociubczyk A, Mendez C, Gregorutti R, Ares A (2015) Electrochemical tests in stainless steel surgical implants. Procedia Materials Science 9: 335-340.

6. http://bone-surgery.ru/view/stalnye_splavy/ 
7. Saravanan M, Devaraju A, Venkateshwaran N, Krishnakumari A, Saarvesh J (2018) A review on recent progress in coatings on AISI austenitic stainless steel. Proceedings Materials 5(6): 14392-14396.

8. Dayane de MeloCosta, Lillian Kelly de OliveiraLopes, Anaclara Ferreira VeigaTipple, Khalid Johani, Honghua Hua, Anand KumarDeva, et al. (2018) Evaluation of stainless-steel surgical instruments subjected to multiple use/processing. Infection, Disease \& Health 23(1): 3-9.

9. Bekmurzayeva A, Duncanson WJ, Azevedo HS, Kanayeva D (2018) Surface modification of stainless steel for biomedical applications: Revisiting a century-old material. Materials Science and Engineering 1(93): 1073-1089.

10. Kalin BA (2001) Radiatsionno-puchkovyye tekhnologii obrabotki konstruktsionnykh materialov .Fizika i khimiya obrabotki materialov 4 : 5-16.

ISSN: 2574-1241

DOI: $10.26717 / B J S T R .2018 .11 .002118$

Vitalii Honcharov. Biomed J Sci \& Tech Res

(c) (i) This work is licensed under Creative

Submission Link: https://biomedres.us/submit-manuscript.php
11. Nikitin AA (1986) Ionnaya implantatsiya - effektivnyy metod izmeneniya svoystv poverkhnosti metallov i splavov. Byulleten TSNIICH 23: 9-18.

12. Cherny AA, Maschenko SV, Honcharov VV, Zazhigalov VA (2015) Nanodimension Layers on Stainless Steel Surface Synthesized by Ionic Implantation and Their Simulation. Nanoplasmonics, Nano-Optics, Nanocomposites, and Surface Studies pp. 203-213.

13. Mashchenko SV, Goncharov VV (2012) Ionnaya implantatsiyaradiatsionno-puchkovaya tekhnologiya modifitsirovaniya materialov. Materialy V mizhnarodnoyi naukovo-praktychnoyi konferentsiyi «Ekonomichni, ekolohichni ta sotsial'ni problemy vuhil'nykh rehioniv SND. Krasnodon pp. 119-121.

14. Honcharov V, Zazhyhalov V (2011) Ionna implantatsiya yak tekhnolohiya poverkhnevoho obroblennya materialiv. Materialy II mizhnarodnoyi konferentsiya molodykh vchenykh EMT-2011, Inzhenerna mekhanika ta transport p. 60-61.

$\begin{array}{ll}\text { BIOMEDICAL } & \text { Assets of Publishing with us } \\ \text { RESEARCHES } & \text { - Global archiving of articles } \\ \text { - Immediate, unrestricted online access }\end{array}$

